\title{
Financial system in the conditions of digitalization of the modern economy
}

\author{
Luza Baiguzina*, Guzalia Galimova and Elvira Nurdavlyatova \\ Bashkir State University, Ufa, Russia
}

\begin{abstract}
This article is devoted to the consideration of the features of the financial system in the context of the digitalization of the modern economy. The authors cite the key aspects of the methodology of scientific knowledge of digital transformation. The methodological approach to defining the digital economy in the financial system is considered. So, as the materials of the theoretical part of the study, the collection, systematization, analysis of data and statistical reference books of the Territorial Body of the Federal State Statistics Service for the Republic of Bashkortostan, reports of the Government of the Republic were used, materials were analyzed to determine the Digital Russia index of the Moscow School of Management Skolkovo and others. numerous open sources of information. The collection and analysis of quantitative and qualitative indicators of digital inequality in the Republic of Bashkortostan was carried out, statistics of indicators of digitalization of the tax system of the Republic were considered
\end{abstract}

\section{Introduction}

The relevance of the scientific article lies in the fact that ensuring economic security for Russia is associated with the introduction of digital technologies along with the developed countries of the world. This issue is especially relevant for the real sector of the economy, the level of digitalization of which will determine the competitiveness of manufactured products, the country's position in the world high-tech markets, which form the preconditions for sustainable development [1].

At the beginning of the XXI century it became quite obvious that revolutionary changes are taking place in the economy under the influence of the rapid spread of various digital technologies. Naturally, economists were faced with the task of determining the contribution of the digital economy to overall economic development, the share of the digital economy in the economies of different countries, the dynamics of the development of the digital economy itself, etc [2]

In this regard, the question naturally arises: how quickly can such a turn be made in the context of the general technological lag of Russia from the developed countries of the world, including in the field of information technology, electronics and element base, when

\footnotetext{
* Corresponding author: Lyuzab@ mail.ru
} 
the country imports about $90 \%$ of hardware and $60 \%$ of software [3]. It is no secret that today Russia is an importer of technologies from abroad, since its own technologies do not always correspond to the world level. In 2015, only $12 \%$ of the developed technologies were fundamentally new and could be competitive in foreign markets, and in the field of industrial information systems, such technologies were only $7.6 \%$. It should be noted that the penetration of digital technologies into the financial system is accompanied by traditional and digital tools for organizing financial activities.

A great burden falls on the support and development of businesses related to the digital economy. The practical implementation and use of digitalization in Russia of public finance has been sufficiently digitized. There are a number of complex digital solutions, platforms that really reduce the subjectivity of decision-making and increase the speed of decisionmaking, this is "Electronic budget"; Unified portal of the budgetary system of the Russian Federation [4]

Everyone knows the program "Digital Economy of the Russian Federation", which is designed for the period until 2024. Funding will require about 522 billion rubles for its implementation, of which 150 billion from the state budget. However, this document has problems and questions that need to be answered. Since in Russia there is neither a common long-term strategy for socio-economic development and there are no clearly formulated structural priorities for industrial development, the development of which is constantly delayed, the adopted digital program is hanging in the air. This raises questions such as: what industries will the digital economy affect? in what state will it be in 5-10 years?

It should be noted that in the section of the presidential decree on the digital economy, it is said about the digital transformation of almost all sectors of the economy and social sphere, including healthcare, education, industry, agriculture, construction, urban services, transport and energy infrastructure, financial services.[5]

The goal is to identify the essence of the digital economy in the financial system and determine the main directions for the introduction of digital technologies into the taxation system.

The term "digital economy" is entering our daily life with rapid steps and the pandemic helped us to move to this platform as urgently as possible. In the course of researching this issue, we studied the publications of domestic and foreign authors that determine the influence of the digital economy in the financial system Nikitenkova M. A. Dahlman C., Mealy S. and Wermelinger M. Gazzani, FlavioI, Rogozhin A. N Federal Law., MolGomez-Vazquez, A Hernandez-Canovas, G; Koeter-Kant, J.

\section{Methods}

The conducted research included both theoretical and practical parts, within the framework of which the set goals and objectives of the work were realized. The collection, systematization, analysis of data and statistical reference books of the Territorial Body of the Federal State Statistics Service for the Republic of Bashkortostan, reports of the Government of the Republic were used as materials for the theoretical part of the study; information sources.

The collection and analysis of quantitative and qualitative indicators of digital inequality in the Republic of Bashkortostan was carried out, statistics of indicators of digitalization of the tax system of the Republic of Bashkortostan were considered.

Based on a systematic analysis of this issue, the theoretical and methodological study revealed that it is necessary to more clearly define the technological priorities for the development of the digital economy in the financial sector. In our opinion, first of all, they 
should be assigned to technological areas, without which digitalization is impossible - this is electronics, and primarily microelectronics, as well as robotics and artificial intelligence.

\section{Results}

The current state of the national economy is reflected in the specifics of the formation and development of regional economies in the Russian Federation. The regions of Russia are highly differentiated by their resource base, industry specialization, and financial security. The lack of the balanced development of the regions expands the horizons of state intervention in economic relations through the mechanisms of tax policy, which is a supporting element of the institution of state regulation. The objective of the work is to study the state of the regional economy based on the example of one of the subjects of the Russian Federation through its tax policy implementation. The conclusions and proposals on the problem under study are formulated in the form of the principles of regional tax policy, the implementation of which, in the authors' opinion, will allow building in the region a differentiated in structure and content mechanism of tax regulation, focused on the expansion of tax potential [6].

Interesting research about exploring alternative environmental taxation system that aims to foster the transition to social-ecological sustainability without affect negatively poor and low-income households. It looks at the potential of environmental fiscal reform in terms of environmental benefits and present in the first section, evidence of some economic regressive impact caused by environmental fiscal reform in European Union from previous empirical studies. The article then introduces of a feedback mechanism to create a repayment system, such as rebate or cash transfer to compensate the regressive effect of the levy being added to the consumer price affecting low-income households in a very short period and push consumers to buy alternative eco-friendly products and services and to stimulate the market to offer them [7,8].

According to research by the Center for Financial Innovation and Cashless Economy of the Moscow School of Management Skolkovo, conducted in October 2018. Using the developed methodology, the Digital Russia index was assessed and calculated for all 85 constituent entities of the Russian Federation. The obtained result showed that the level of implementation of digitalization in the constituent entities of the Russian Federation changes from year to year and differs significantly. This is reflected in the summary table of the results of calculating the digitalization index (given in Appendix 1). For clarity of the research results, out of 85 constituent entities of the Russian Federation, 10 leaders of the constituent entities of the Russian Federation can be distinguished (Table 1)

Table 1. 10 leaders of the constituent entities of the Russian Federation.

\begin{tabular}{|c|c|c|c|c|c|c|}
\hline \multirow[b]{2}{*}{ № } & \multirow[b]{2}{*}{$\begin{array}{c}\text { The subject of the Russian } \\
\text { Federation }\end{array}$} & \multirow[b]{2}{*}{$\begin{array}{c}\text { Score in } \\
2018\end{array}$} & \multicolumn{4}{|c|}{ Change in 2018 to 2017} \\
\hline & & & $\begin{array}{c}\text { Score in } \\
2017\end{array}$ & $\begin{array}{l}\text { Place in } \\
2017\end{array}$ & $\begin{array}{c}\text { Place }(+/- \\
)\end{array}$ & Change (\%) \\
\hline 1 & Moscow & 77,03 & 70,01 & 1 & 0 & $10,02 \%$ \\
\hline 2 & Republic of Tatarstan & 76,48 & 67,95 & 2 & 0 & $12,56 \%$ \\
\hline 3 & Saint Petersburg & 76,44 & 67,54 & 4 & 1 & $13,18 \%$ \\
\hline 4 & Moscow region & 76,25 & 65,61 & 6 & 2 & $16,22 \%$ \\
\hline 5 & Tyumen region & 76,19 & 65,44 & 7 & 2 & $16,43 \%$ \\
\hline 6 & KMAO - Ugra & 75,81 & 67,88 & 3 & -3 & $11,69 \%$ \\
\hline 7 & Yamalo Nenets AO & 74,48 & 66,03 & 5 & -2 & $12,79 \%$ \\
\hline 8 & Republic of Bashkortostan & 74,43 & 65,08 & 8 & 0 & $14,36 \%$ \\
\hline 9 & Leningrad region & 73,15 & 62,45 & 12 & 3 & $17,13 \%$ \\
\hline 10 & Novosibirsk region & 73,10 & 52,48 & 33 & 23 & $39,29 \%$ \\
\hline
\end{tabular}


The results show that, on a 100-point scale, the interval of indicators of the Digital Russia index in the first half of 2018 narrowed and is in the range from 39.74 to 77.03 points (in 2017 this interval was 26.06-70.01) ... This result indicates a significant reduction in the gap between the leading and the lowest rating constituent entities of the Russian Federation. The difference in the index values between first and last place in 2018 decreased by $17.86 \%$ [9]

The leader among the subjects of the Russian Federation is the city of Moscow. The leadership of the city of Moscow, based on the data obtained, is based on the continuous improvement of its Information City program since 2012. In addition, Moscow is actively working with the federal center, its representatives are included in the expert groups created under the ANO Tsifrovaya ekonomika; a number of areas that are provided for in the federal program "Digital Economy of Russia" are already being tested in the city of Moscow at the level of specific business cases, which also contributes to the leadership of this subject.

Numerical indicators of sub-indices for the Republic of Bashkortostan are presented in Figure 1, the final complex indicator of the index is 71.29.

Regulatory regulation

Specialized personnel and training
programs

Information infrastructure

Information Security

Economic indicators of digitalization

The social effect of digitalization

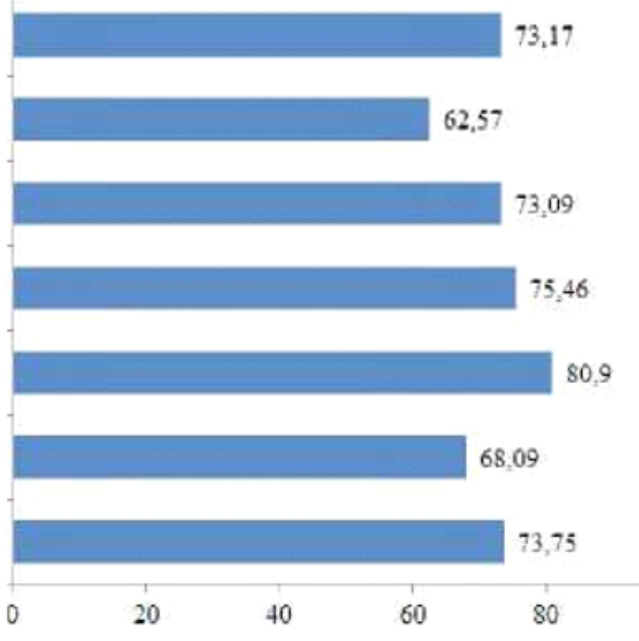

Fig. 1. Indicators of the "Digital Russia" index for the Republic of Bashkortostan (in points)

Digital inequality is also associated with the economic differentiation of the population in terms of income. According to the Federal State Statistics Service for the Republic of Bashkortostan, in 2017, $16.7 \%$ of the republic's population had an average per capita income of less than 10 thousand rubles. per month, $16.2 \%$ - monthly income from 10 to 15 thousand rubles. With incomes of this level, the population does not have the opportunity to purchase modern high-tech digital gadgets, they have to limit themselves in the amount of payment for mobile communications and the Internet [10]

Let's consider in what directions the development and use of digital technologies in taxation is carried out. The transformation of financial sustainability can be affected by the introduction of digitalization of the financial system. In connection with the prevailing economic conditions at this time, government expenditures have increased, which undoubtedly requires an increase in budget revenues, respectively, an increase in the tax burden. At the same time, the government has taken a number of measures to help defer tax payments or reduce the tax burden for certain sectors of the economy, especially small businesses. In connection with the current circumstances, it is relevant to assess the tax 
burden at different economic levels (country, region, industry, organization) before and after the pandemic.

Based on the analysis of the sectoral structure of business in the Republic of Bashkortostan, it follows that the largest share of the services provided falls on the transportation of passengers and rental of residential premises and others. The share of nonstate carriers is about $95 \%$, some of which are "illegal". Let us consider using this example the possibility of using the NAP. Today, the sphere of passenger transportation is under the close scrutiny of regulatory authorities, that is, if the carrier does not have the necessary documents, passengers will be left without transport, and drivers without work. PIT is a convenient solution for citizens who want to carry out transportation, drivers will be able to work legally and on good conditions.

Despite the fact that the main function of taxes is to provide financial support for the activities of the state, this tax is not fiscal, but social. NAP has a number of advantages, in order to become a payer of this tax there is no need to visit the tax authority, registration and deregistration takes place through the free application "My Tax", thus interaction with the tax authority is available at any time. It should be noted that PIT payers do not have an obligation to provide reporting, as well as to pay insurance premiums. Also, there is no need to install cash registers, since all receipts are generated in the application.

For more information, you can contact any tax authority or use the electronic services of the Federal Tax Service of Russia.[11]

Within the framework of the federal project "Creating favorable conditions for an easy start and comfortable doing business", the Federal Tax Service plans in 2021 to introduce the "USN-Online" system for automatic accounting of income in an online mode. This will exclude the obligation to submit a tax return for small and medium-sized businesses. There are 1.2 million of them in the Federal Tax Service in Russia. The tax authority will calculate the tax on its own based on data received from online cash registers [12]

In 2021, it is also planned to create a new unified consolidated register of arrears on payments to the budget. And, as it were, complements this event with the initiative of the Federal Tax Service together with the Federal Bailiff Service (FSSP) to develop a plan to improve the efficiency of collection of debts on mandatory payments.

A high level of profit today is typical for entrepreneurs who create business platforms on the Internet; this format most fully meets the needs of our time. Such changes may in the future transform the taxation system in the state. Such transformations are necessary, first of all, in tax administration, which must be adapted to the conditions of the digital economy.

Thus, it is necessary to create a tax base and tax control, which completely exclude the possibility of tax evasion in absolutely any business. This can be achieved through the use of modern digitalization technologies.

\section{Discussion}

Improving the efficiency of the functioning of the financial system of the region largely depends on the budgetary system of the region, the volume of fiscal powers of state authorities and local self-government, as well as the efficiency and effectiveness of spending budget funds, including financial support for the regional economy.

Traditionally, the overwhelming majority of small and medium-sized businesses in Russia are engaged in trade and the provision of services, i.e. it was these businesses that were the first to suffer from the restrictions during the pandemic.

Considering that SMEs are already characterized by difficulties in attracting sources of financing for activities, including by obtaining borrowed funds due to the high interest rate on loans and borrowings; hypersensitivity to any changes in the global and national 
economy; a higher level of risk compared to large enterprises, catastrophic results of a pandemic in this area should be expected. In accordance with the Federal Law "On the Development of Small and Medium Enterprises in the Russian Federation" dated July 24, 2007 No. 209-FZ, the average number of employees in micro-enterprises should not exceed 15 people, small enterprises - 100 people, and medium-sized enterprises - 250 people [13].Thus, the maximum values of income received from the implementation of entrepreneurial activity should not exceed 120 million rubles for a micro-enterprise; for small businesses - 800 million rubles; for medium-sized enterprises - 2 billion rubles [14]

It would be difficult not to agree, there are significant differences in the capabilities and needs for digitalization among enterprises with revenues of 1.5 million and 1.5 billion rubles.

The lack of coherent and clear criteria complicates the assessment of the level of digitalization of SMEs. According to a witty remark, "to stay ahead of competitors in digitalization, it is enough to use electronic document management, CRM, online advertising and free antivirus." [15]

To prove the above, we need to highlight the promotion of a more stable European banking system has become a priority which, not doubt, will bring important benefits to firms. However, bank stability comes with stronger regulations that could harm the access to finance of small and medium-sized enterprises (SMEs), which are highly dependent on bank financing. We provide new evidence on the association between the stability of a country's banking system and SMEs access to finance through the study of borrower discouragement. We analyze 20,207 observations gathered among 16,382 firms operating in the EU-28 during the period 2011-2018. Applying multilevel methodology, our results show that SMEs operating in countries with more stable banking systems are less likely to be discouraged from applying for a loan. Working to achieve a more stable banking system does not seem to harm the access to finance of SMEs [16]

\section{Conclusion}

The emergence of the newest financial instruments based on digital technologies in the modern economy requires solving a number of problems in taxation; not only the state, but also market participants - taxpayers are interested in solving these taxation issues, since the absence of specific legal aspects of the definition of digital money does not represent an opportunity amendments to the Tax Code and other legislative acts on taxes and fees of the Russian Federation [17]

In the near future, there will be a change in companies that extract minerals, pay the state mining rent in the form of royalties tied to the price of resources. In Russia, it now depends on the cost of production costs, which is several times less than the market price for such natural resources. Also, starting from the new year, all severance tax benefits for depleted fields will be canceled. This will bring 260 billion rubles to the treasury. Also, additional revenues to the state budget will be brought by updated agreements on the avoidance of double taxation with some countries. This spring, Vladimir Putin ordered to increase the tax on the transfer of dividends and interest to foreign accounts to $15 \%$. The innovations will take effect from the beginning of next year. If some of the countries do not support these measures, Russia will unilaterally withdraw from such agreements. Also, a key moment in replenishing the country's income will be an increase in personal income tax for Russians, whose earnings per year exceed 5 million rubles. The tax increased from 13 to 15 percent. As a result, from 2021 to 2023, the country's budget is expected to receive an additional 190 billion rubles. This money will be used to treat children with serious illnesses. 


\section{References}

1. E.B. Lenchuk, G.A. Vlaskin, Bulletin of IE RAS, 5, 9 (2018)

2. Yu.V. Belousov, O. I. Timofeeva, Mir novoj èkonomik, 13, 4 (2019)

3. Contours of Digital Reality: Humanitarian and Technological Revolution and Choice of the Future (LENAND, 2018)

4. Mobile application E-Budget, http://budget.gov.ru

5. E.B. Lenchuk, G.A. Vlaskin, Economics and Management, 5, 9 (2018)

6. R.V. Batashev, T.V. Deeva, O.F. Shakhov, Turismo: Estudos e Práticas Rua Antônio Victor, Rincão, Mossoro, CEP59626-310 (2021)

7. G. Flavio, International Journal of Social Economics, 0656 (2020)

8. J. Brandt, J.D. Silver, J.H. Christensen, Atmospheric Chemistry and Physics, 13, 15 (2013)

9. Index "Digital Russia", Center for Financial Innovation and Cashless Economy of the Moscow School of Management Skolkovo, https://finance.skolkovo.ru/downloads/documents/FinChair/Research_Reports/SKOLK OVO_Digital_Russia_Report_Full_2018-10_ru.pdf

10. Territorial body of the Federal State Statistics Service in the Republic of Bashkortostan, https://clck.ru/FPGs3 Tax burden in the system of tax policy of the state and organizations, https://search.rsl.ru/ru/record/01005055767

11. Federal Law " On the development of small and medium-sized businesses in the Russian Federation "dated 24.07.2007 No. 209-FZ (last edition), http://www.consultant.ru/document/cons_doc_LAW_52144

12. Decree of the Government of the Russian Federation of 04.04.2016 No. 265 "On the limit values of income received from entrepreneurial activities for each category of small and medium-sized businesses", http: //www.consultant.ru/document/cons_doc_LAW_196415/\#dst100005

13. Digitalization of business processes is a chance for small and medium enterprises, https://expert.ru/2019/07/16/tsifrovizatsiya-biznes-protsessov---shans-dlya-malyih-isrednih-predpriyatij/

14. A. Mol-Gomez-Vazquez, G. Hernandez-Canovas, J. Koeter-Kant, Small Business Economics, 21(1),37 (2020)

15. E.L. Gulkova, M.V. Karp, M.V. Tipalina, Bulletin of the University, 4, 65 (2019) 